\title{
Drug Dosing Considerations in Critically Ill Patients Receiving Continuous Renal Replacement Therapy
}

\author{
Soo Min Jang ${ }^{1, *(\mathbb{D})}$, Sergio Infante ${ }^{2}$ and Amir Abdi Pour ${ }^{2}$ (1) \\ 1 School of Pharmacy, Loma Linda University, Loma Linda, CA 92350, USA \\ 2 School of Medicine, Loma Linda University, Loma Linda, CA 92350, USA; sinfante@llu.edu (S.I.); \\ aabdipou@llu.edu (A.A.P.) \\ * Correspondence: smjang@llu.edu; Tel.: +1-909-558-7730
}

Received: 31 December 2019; Accepted: 4 February 2020; Published: 7 February 2020

\begin{abstract}
Acute kidney injury is very common in critically ill patients requiring renal replacement therapy. Despite the advancement in medicine, the mortality rate from septic shock can be as high as $60 \%$. This manuscript describes drug-dosing considerations and challenges for clinicians. For instance, drugs' pharmacokinetic changes (e.g., decreased protein binding and increased volume of distribution) and drug property changes in critical illness affecting solute or drug clearance during renal replacement therapy. Moreover, different types of renal replacement therapy (intermittent hemodialysis, prolonged intermittent renal replacement therapy or sustained low-efficiency dialysis, and continuous renal replacement therapy) are discussed to describe how to optimize the drug administration strategies. With updated literature, pharmacodynamic targets and empirical dosing recommendations for commonly used antibiotics in critically ill patients receiving continuous renal replacement therapy are outlined. It is vital to utilize local epidemiology and resistance patterns to select appropriate antibiotics to optimize clinical outcomes. Therapeutic drug monitoring should be used, when possible. This review should be used as a guide to develop a patient-specific antibiotic therapy plan.
\end{abstract}

Keywords: antibiotics; drug dosing; acute kidney injury; continuous renal replacement therapy; pharmacokinetics; pharmacodynamics

\section{Introduction}

Continuous renal replacement therapy (CRRT) is commonly used in critically ill patients with acute kidney injury (AKI) due to life-threatening fluid overload and/or electrolyte abnormalities. Mortality rate from septic shock is still high (60\%), despite the advancement in medicine [1]. The 2016 Sepsis Surviving Guideline suggests clinicians to administer the appropriate dose of antibiotic as soon as the septic shock is recognized [2]. Many drugs used in critically ill patients with AKI can be titrated to effect (pain medications, sedatives, and vasopressors). However, the serum concentrations of most antibiotics cannot be measured or titrated in the clinical setting. Consequently, the empiric dosing regimen must be correct with the first dose. This paper will focus on antibiotic agents and how to optimize antibiotic dosing strategies (time- vs. concentration-dependent) depending on their pharmacodynamics (PD) targets.

\section{Drug Dosing Challenges for Clinicians}

Continuous renal replacement therapy (CRRT) has been the preferred treatment choice for hemodynamically unstable patients with acute kidney injury (AKI). It is better tolerated by critically ill patients than intermittent hemodialysis (IHD). However, delivery of CRRT at any given hospital can vary due to differences in anticoagulation (heparin vs. sodium citrate), CRRT modality (continuous veno-venous hemofiltration (CVVH), continuous veno-venous hemodialysis (CVVHD), continuous 
veno-venous hemodiafiltration (CVVHDF), replacement solution administration, and prescribed effluent rates. Additionally, hybrid renal replacement therapy (RRT), such as prolonged intermittent renal replacement therapy (PIRRT) or sustained low-efficiency hemodialysis (SLED), adds another layer of complexity of appropriate antibiotic dosing in critically ill patients. Clinicians are hesitant to utilize hybrid RRTs, despite the benefits of IHD and CRRT (ex., cost-effective and well-tolerated by hemodynamically unstable patients [3]). There is a scarcity of pharmacokinetic (PK) data in hybrid RRT and inconsistency of variability in hybrid RRT operating parameters. Thus, clinicians often need to extrapolate PK data from in vitro reports, case reports, or studies conducted from a variety of RRT modalities to determine drug dosing. A study in critically ill patients receiving CRRT showed that only $53 \%$ of those received ceftazidime treatment, and $0 \%$ of those receiving cefepime treatment achieved the desired pharmacodynamic targets against P. aeruginosa [4]. A drug like piperacillin has wide interindividual variability in critically ill patients and may not reach the probability of target attainments (PTA) [5]. Therapeutic drug monitoring (TDM) is being utilized for $\beta$-lactams (piperacillin or meropenem) in some hospitals to individualize the therapy [6]. However, it is not available at the majority of medical centers. For drugs that require TDM, ensure the blood sample is collected outside the CRRT system or from a pre-filter port to avoid underestimation of the patient's drug concentration. A working knowledge of how CRRT is delivered to a particular patient is critical to develop an appropriate personalized pharmacotherapy $[7,8]$. The goal of therapy in critically ill patients with sepsis should be the administration of appropriate antibacterial drugs within one hour of sepsis recognition to decrease morbidity and mortality [9]. Each one-hour delay in effective antibiotic administration is associated with increased mortality [10]. The clinician must ensure that the "appropriate" drug is selected with the adequate dose accounting for CRRT clearance and the altered PK in critical illness.

\section{Pharmacokinetic Changes in Critically Ill Patients with Sepsis}

Due to increased capillary permeability and fluid accumulation from sepsis, volume of distribution $(\mathrm{Vd})$ of antibiotic is increased. Hydrophilic antibiotics like $\beta$-lactams are more affected than lipophilic antibiotics such as fluoroquinolones. Up to one-half of all critically ill patients may develop hypoalbuminemia, which will directly affect the drug $\mathrm{Vd}$ by increasing the unbound drug fraction of highly protein-bound drugs [11]. An increase in unbound drug concentrations may enhance pharmacologic effects and increase the toxicity risk. Additionally, higher free drug concentrations increase the amount of drug available to be dialyzed by RRT. Critically ill patients with AKI will likely have a decreased non-renal clearance $\left(C L_{N R}\right)$ compared to healthy individuals but higher $C_{N R}$ compared to end-stage renal disease (ESRD). The difference between some drugs' $\mathrm{CL}_{\mathrm{NR}}$ almost doubled in critically ill patients with AKI compared to ESRD patients. For example, imipenem's CL $L_{N R}$ was $95 \mathrm{~mL} / \mathrm{min}$ in critically ill patients with AKI, whereas it was $50 \mathrm{~mL} / \mathrm{min}$ in ESRD patients [12,13]. Vancomycin's CL $\mathrm{NR}_{\mathrm{N}}$ was reported to be $15 \mathrm{~mL} / \mathrm{min}$ in AKI patients compared to $5 \mathrm{~mL} / \mathrm{min}$ in ESRD patients [14-16]. Surprisingly, meropenem's $\mathrm{CL}_{\mathrm{NR}}$ for patients with normal renal function $\left(\mathrm{CL}_{\mathrm{NR}}\right.$ 45-60 mL/min) [17-19] was reported to be similar to AKI patients' (CL $\mathrm{L}_{\mathrm{NR}} 40-60 \mathrm{~mL} / \mathrm{min}$ ) [20,21].

\section{Types of Renal Replacement Therapy}

Drug removal is influenced by the mode of RRT, frequency of dialysis, and flow rates of RRT. Filters that are used in RRT influence the drug removal. However, high-flux filters are commonly used in current clinical settings. Thus, the influence of filter types will not be discussed in this paper. Increased RRT frequency will result in more drug removal. Since there is no data to prove a superiority of any type of RRT [22], it is important to consider how fast the antibiotic is being removed by different RRT modalities. Generally, the slowest rate between blood and effluent (dialysate and/or ultrafiltrate) rate is the one that ultimately determines solute clearance. For example, in intermittent hemodialysis, the dialysate rate is usually twice the blood flow rate; consequently, it is blood flow that determines the dialytic clearance. 
Intermittent hemodialysis provides a rapid (usually 3-5 h) RRT that is often performed thrice-weekly in outpatient regimens. IHD provides much higher extracorporeal drug clearance than other RRTs. For example, blood flow rate ranges between $250-450 \mathrm{~mL} / \mathrm{min}$ for IHD, $150-400 \mathrm{~mL} / \mathrm{min}$ for PIRRT, and 150-250 mL/min for CRRT. The dialysate flow rate ranges $500-800 \mathrm{~mL} / \mathrm{min}$ for IHD, $100-300 \mathrm{~mL} / \mathrm{min}$ for PIRRT, and 1-3 L/h for CVVHD and CVVHDF. Ultrafiltration rates are 1-3 L per 3-5 h of IHD, 1-4 L per $6-12 \mathrm{~h}$ of PIRRT and 1-3 L/h for CVVH and CVVHDF [23]. The main drug removal during non-IHD treatment for the patients would be $\mathrm{CL}_{\mathrm{NR}}$. Many drug package inserts provide drug dosing recommendations for hemodialysis patients. However, these dose recommendations are not applicable in critically ill patients receiving IHD, since these PK data are predominantly generated in ESRD patients. PK parameters are not only markedly different in this patient population, but also, hypercatabolic critically ill patients may require more frequent IHD ( $>3$ times weekly) to control electrolyte and waste product removal [24]. Drug dosing regimens that are appropriate for a thrice-weekly hemodialysis schedule are unlikely to benefit patients needing IHD five to seven times per week.

Prolonged intermittent renal replacement therapy or sustained low-efficiency dialysis is a type of hybrid RRT to achieve the benefits of IHD and CRRT. The PIRRT is usually operated for 6-10 h daily. It can be used in hemodynamically unstable patients and is cost-effective compared to CRRT [3]. Moreover, it can provide an opportunity for procedures or physical therapy during downtime without limiting dialytic treatment. Yet, the inconsistency with PIRRT regimens complicates drug dosing. Prescriptions for PIRRT are different from institution to institution, and drugs that needs to be given every $6-8 \mathrm{~h}$ must sometimes be administered while PIRRT is operating. This leads to questions such as "Do you administer the drug before, during, or after PIRRT?" and "Do I need to give higher doses while PIRRT is running than when PIRRT is turned off?" The complexity of drug dosing in PIRRT is also reflected in the survey of 69 experienced American critical care pharmacists. They were surveyed for PIRRT dosing recommendations for cefepime, ceftaroline, daptomycin, levofloxacin, meropenem, and piperacillin/tazobactam [25]. Up to nine distinct regimens per antibiotic were recommended, and total daily doses varied from 4- to 12-fold. The wide drug dosing ranges by experienced pharmacists show that guidance with PIRRT antibiotic dosing is inadequate and varies widely, leading to lack of standardization.

Continuous renal replacement therapy is intended to run $24 \mathrm{~h} /$ day, which allows hemodynamically unstable patients with AKI to utilize it. Yet, CRRT interruptions do often occur. It has been reported that the prescribed CRRT clearance was overestimated by $24 \%$ compared to the actual delivered clearance at an academic medical center [26]. This shows that prescribed CRRT doses may significantly be overestimated compared to the actual delivered clearance, leading to potential drug accumulation. Clinicians should adjust the drug dosing regimen if CRRT has been interrupted. Unlike IHD, drug clearance for CRRT can be calculated (Table 1). In order to calculate the CRRT drug clearance, clinicians need to determine the sieving coefficient (SC) and saturation coefficient (SA) for solutes. The SC and SA describe a solute's ability to cross the hemodiafilter membrane in CVVH and CVVHD, respectively. Both terms are expressed as the concentration of drug/solute in ultrafiltrate or dialysate relative to plasma. The SC and SA can range from 0 (no drug clearance via CRRT) to 1 (drug is freely cleared by CRRT). These terms are often used interchangeably. The SC can be determined by measuring solute concentrations from ultrafiltrate and the solute concentration from the patient's blood. It can be calculated by [concentration in ultrafiltrate]/[concentration in blood]. In the absence of drug concentrations, it can be estimated as SC $=1$ - protein binding (PB). Drug PB rates in critically ill patients can be difficult to determine, because PK studies are limited; consequently, "normal" rates are often used. The latter approach is less accurate, because critically ill patients may have different $\mathrm{PB}$ rates compared to healthy subjects from low serum albumin concentrations and retained waste products. Table 1 shows equations to calculate CRRT solute clearance depending on CRRT modalities. Replacement fluids must be administered when convection is used to replace the ultrafiltrate produced to prevent hypovolemia. Replacement solutions can be infused into any of the ports (pre-filter or post-filter) that exist in the extracorporeal CRRT circuit. Drug removal by CRRT is affected by where a replacement solution is infused into the extracorporeal circuit. Drug concentration is diluted in 
the filter when the fluid is infused as a pre-filter, resulting in decreased drug removal in pre-filter CVVH. Conversely, the drug is removed very efficiently across the hemodiafilter membrane when the replacement solution is infused as a post-filter. Although pre-filter fluid replacement CRRT reduces solute clearance, it prevents having a filter clogging (when hematocrit concentration increases within the hemodiafilter, it results in a thick and viscous blood). Since a CRRT machine will stop when the filter is clogged, many medical centers use pre-filter CVVH, despite knowing that the CRRT solute/drug removal will be less efficient than post-filter CVVH [23]. A "correction" factor for pre-filter fluid replacement appears in Table 1.

Table 1. Equations for calculating continuous renal replacement therapy (CRRT) clearance $[23,27]$.

\begin{tabular}{|c|c|c|}
\hline CRRT Types & CRRT Clearance Equations & Solute Removal \\
\hline CVVH pre-dilution & $\mathrm{CL}_{\mathrm{CVVH}}($ pre $)=\mathrm{Q}_{\text {eff }} \times \mathrm{SC} \times\left(\frac{\mathrm{Qb}}{\mathrm{Qb}+\mathrm{Qrep}}\right)$ & $\begin{array}{c}\text { Convection } \\
\text { (influence of gravity) }\end{array}$ \\
\hline CVVH post-dilution & $\mathrm{CL}_{\mathrm{CVVH}(\text { post })}=\mathrm{Q}_{\mathrm{eff}} \times \mathrm{SC}$ & Convection \\
\hline CVVHD & $\mathrm{CL}_{\mathrm{CVVHD}}=\mathrm{Q}_{\mathrm{d}} \times \mathrm{SA}$ & $\begin{array}{c}\text { Diffusion } \\
\text { (concentration gradient) }\end{array}$ \\
\hline CVVHDF & $\mathrm{CL}_{\mathrm{CVVHDF}}=\left(\mathrm{Q}_{\mathrm{uf}}+\mathrm{Q}_{\mathrm{d}}\right) \times \mathrm{SA}$ & Convection + diffusion \\
\hline \multicolumn{3}{|c|}{$\begin{array}{l}\text { CVVH(pre) = pre-dilution continuous veno-venous hemofiltration; } \mathrm{CVVH}(\text { post })= \\
\text { post-dilution continuous veno-venous hemofiltration; } \mathrm{CVVHD}=\text { continuous veno-venous } \\
\text { hemodialysis; CVVHDF = continuous veno-venous hemodiafiltration; } \mathrm{SA}=\text { saturation } \\
\text { coefficient; } \mathrm{SC}=\text { sieving coefficient; } \mathrm{Q}_{\mathrm{b}}=\text { blood flow rate; } \mathrm{Q}_{\mathrm{d}}=\text { dialysate flow rate; } \\
\mathrm{Q}_{\text {eff }}=\text { effluent flow rate; } \mathrm{Q}_{\mathrm{rep}}=\text { replacement fluid rate; } \mathrm{Q}_{\mathrm{uf}}=\text { ultrafiltration rate }\end{array}$} \\
\hline
\end{tabular}

\section{Drug Administration Strategies in CRRT}

\subsection{Drug Specific Considerations}

Drugs' molecular weight (MW) and PB affect RRT drug clearance. The larger the MW, the more difficult it is for the drug to cross the hemodiafilter membrane. For example, blood proteins are too large to be cleared by the membrane, highly protein-bound drugs will remain in the blood (not removed by CRRT). Blood, dialysate, and ultrafiltrate rates can be independently prescribed to meet solute and fluid removal goals in any RRT. Generally, the slowest rate between blood or dialysate + ultrafiltrate rate is the one that ultimately determines a solute clearance. Aforementioned blood flow is usually much higher than that of the effluent (dialysate + ultrafiltrate) rate in CRRT. Thus, the effluent rate determines the drug clearance by CRRT. The faster the effluent rate, the more drug removal will occur in patients receiving CRRT. However, intensity of CRRT effluent rates $(25 \mathrm{~mL} / \mathrm{kg} / \mathrm{h}$ vs. $35 \mathrm{~mL} / \mathrm{kg} / \mathrm{h})$ did not show any differences in clinical outcome [28]. Moreover, a recent Monte Carlo simulation study showed the intensity of effluent rates did not influence the PTA for selected $\beta$-lactam drugs [29].

\subsection{Time-Dependent vs. Concentration-Dependent Antibiotics}

In general, antibiotics are classified as: (1) concentration-dependent (e.g., aminoglycosides and fluoroquinolones); (2) time-dependent (e.g., $\beta$-lactams and carbapenems); or (3) both (e.g., vancomycin). Concentration-dependent antibiotics are most effective when drugs reach maximum concentration (Cmax) values relative to the target organism's minimum inhibitory concentration (MIC). Time-dependent antibiotics are optimized when the time that the serum concentration is above the minimum inhibitory concentration $(\mathrm{T} \geq \mathrm{MIC}$ ) is maximized. In antibiotics that require both concentration- and time-dependent PD targets, the PD target is defined as an area under the curve (AUC) for $24 \mathrm{~h}$ over MIC ( $\mathrm{AUC}_{0-24} / \mathrm{MIC}$ ). Table 2 lists published PD targets and empiric dosing recommendations for adult patients with AKI who are receiving any form of CRRT at different effluent flow rates (Qeff). Even though the Qeff has been defined in the table, the Qeff has been shown to insignificantly affect the PTA of different antibiotics [29]. 
Table 2. Intravenous (IV) drug dosing recommendations during CRRT [23,30-34].

\begin{tabular}{|c|c|c|c|c|}
\hline Medication & Accepted PD Target & $\begin{array}{c}\text { Aronoff } \\
\left(Q_{\text {eff }} 33 \mathrm{~mL} / \mathrm{min}\right)\end{array}$ & $\begin{array}{l}\text { Hoff/Heintz CVVH } \\
\left(Q_{\text {eff }} 17-33 \mathrm{~mL} / \mathrm{min}\right)\end{array}$ & $\begin{array}{c}\text { Jang } \\
\left(\mathrm{Q}_{\text {eff }} 25 \mathrm{~mL} / \mathrm{kg} / \mathrm{h}\right)\end{array}$ \\
\hline \multicolumn{5}{|c|}{ Aminoglycosides (CD) } \\
\hline Amikacin & $\begin{array}{c}\mathrm{Cmax} / \mathrm{MIC} \geq 10 \mathrm{mg} / \mathrm{L} ; \\
\mathrm{AUC}_{0-24} / \mathrm{MIC} \geq \\
70-120 \mathrm{mg} \cdot \mathrm{h} / \mathrm{L}\end{array}$ & $\begin{array}{l}7.5 \mathrm{mg} / \mathrm{kg} \text { q12h or } \\
15 \mathrm{mg} / \mathrm{kg} \text { q24-72h } \\
\text { by concentrations }\end{array}$ & $\begin{array}{c}10 \mathrm{mg} / \mathrm{kg} \text { LD, } \\
7.5 \mathrm{mg} / \mathrm{kg} \text { q24-48h }\end{array}$ & $\begin{array}{c}10-15 \mathrm{mg} / \mathrm{kg} \mathrm{LD}, 7.5 \mathrm{mg} / \mathrm{kg} \\
\text { re-dose when trough } \\
\text { concentrationsn }<5 \mathrm{mg} / \mathrm{L}\end{array}$ \\
\hline Gentamicin & $\begin{array}{c}\mathrm{Cmax} / \mathrm{MIC} \geq 10 \mathrm{mg} / \mathrm{L} ; \\
\mathrm{AUC}_{0-24} / \mathrm{MIC} \geq 70-120 \\
\mathrm{mg} \cdot \mathrm{h} / \mathrm{L}\end{array}$ & $\begin{array}{c}1.7 \mathrm{mg} / \mathrm{kg} \text { q8h or } \\
5-7 \mathrm{mg} / \mathrm{kg} \text { q12-48h } \\
\text { by concentrations }\end{array}$ & $\begin{array}{l}2-3 \mathrm{mg} / \mathrm{kg} \mathrm{LD}, \\
\text { systemic GNR } \\
\text { infection } \\
1.5-2.5 \mathrm{mg} / \mathrm{kg} \mathrm{q} 24-48 \mathrm{~h}\end{array}$ & $\begin{array}{l}2-3 \mathrm{mg} / \mathrm{kg} \mathrm{LD}, \text { re-dose } \\
\text { when trough } \\
\text { concentrations }<1 \mathrm{mg} / \mathrm{L}\end{array}$ \\
\hline \multicolumn{5}{|c|}{ Penicillin (TD) } \\
\hline $\begin{array}{l}\text { Piperacillin/ } \\
\text { tazobactam }\end{array}$ & $\begin{array}{c}\geq 50 \% f \mathrm{~T} \geq 16 / 4 \mathrm{mg} / \mathrm{L} \\
\quad(\text { P. aeruginosa })\end{array}$ & $4.5 \mathrm{~g} \mathrm{q} 8 \mathrm{~h}$ & $\begin{array}{c}3.375 \mathrm{~g} \mathrm{q} 8 \mathrm{~h} \\
\text { 4-hour infusion }\end{array}$ & $4.5 \mathrm{~g} \mathrm{q} 8 \mathrm{~h}$ \\
\hline $\begin{array}{l}\text { Ampicillin/ } \\
\text { sulbactam }\end{array}$ & $\begin{array}{l}\geq 50 \% f \mathrm{~T} \geq 8 / 4 \mathrm{mg} / \mathrm{L} \\
\text { (Acinetobacter spp.) }\end{array}$ & $\mathrm{N} / \mathrm{A}$ & 3 g LD, $1.5-3$ g q8-12h & $3 \mathrm{~g} \mathrm{q} 8-12 \mathrm{~h}$ \\
\hline \multicolumn{5}{|c|}{ Cephalosporins (TD) } \\
\hline Cefepime & $\begin{array}{l}\geq 70 \% f \mathrm{~T} \geq 8 \mathrm{mg} / \mathrm{L} \\
\quad(\text { P. aeruginosa })\end{array}$ & $1-2 \mathrm{~g} \mathrm{q} 12 \mathrm{~h}$ & $\begin{array}{l}\text { 30minute infusion } \\
\text { 1L/h: } 1 \text { g q8h } \\
\text { 2-3 L/h: } 1 \text { g q6h }\end{array}$ & $\begin{array}{c}2 \mathrm{~g} \mathrm{LD}, \\
1 \mathrm{~g} \mathrm{q} 8-12 \mathrm{~h}\end{array}$ \\
\hline Ceftazidime & $\begin{array}{l}\geq 70 \% f \mathrm{~T} \geq 8 \mathrm{mg} / \mathrm{L} \\
\quad(P . \text { aeruginosa })\end{array}$ & $\begin{array}{l}\text { 1-2 g q12h or } 2 \mathrm{~g} \\
\mathrm{LD}, \text { followed by } 3 \\
\text { g/day continuous } \\
\text { infusion }\end{array}$ & $2 \mathrm{~g} \mathrm{LD}, 1-2 \mathrm{~g} \mathrm{q} 12 \mathrm{~h}$ & $\begin{array}{c}2 \mathrm{~g} \mathrm{LD}, \\
1-2 \mathrm{~g} \mathrm{q} 12 \mathrm{~h}\end{array}$ \\
\hline \multicolumn{5}{|c|}{ Carbapenems (TD) } \\
\hline Meropenem & $\begin{array}{l}\geq 40 \% f \mathrm{~T} \geq 2 \mathrm{mg} / \mathrm{L} \\
\quad(P . \text { aeruginosa })\end{array}$ & $1-2$ g q12h & $\begin{array}{c}\text { 3-hour infusion } \\
0.5 \mathrm{~g} \mathrm{q} 8 \mathrm{~h}\end{array}$ & $1 \mathrm{~g} \mathrm{q} 8-12 \mathrm{~h}$ \\
\hline Doripenem & $\begin{array}{c}\geq 40 \% f \mathrm{~T} \geq 2 \mathrm{mg} / \mathrm{L} \\
\quad(P . \text { aeruginosa })\end{array}$ & N/A & $\mathrm{N} / \mathrm{A}$ & $500 \mathrm{mg} \mathrm{q} 8 \mathrm{~h}$ \\
\hline Imipenem & $\begin{array}{l}\geq 40 \% f \mathrm{~T} \geq 2 \mathrm{mg} / \mathrm{L} \\
\quad(P . \text { aeruginosa })\end{array}$ & $500 \mathrm{mg} \mathrm{q} 6 \mathrm{~h}$ & $1 \mathrm{~g} \mathrm{LD}, 500 \mathrm{mg}$ q8h & $500 \mathrm{mg}$ q6h \\
\hline Ertapenem & $\begin{array}{c}\geq 40 \% f \mathrm{~T} \geq 2 \mathrm{mg} / \mathrm{L} \\
\text { (Streptococcus } \\
\text { pneumoniae) }\end{array}$ & $1 \mathrm{~g} \mathrm{q} 24 \mathrm{~h}$ & N/A & $1 \mathrm{~g} \mathrm{q} 24 \mathrm{~h}$ \\
\hline \multicolumn{5}{|c|}{ Fluoroquinolones (CD) } \\
\hline Levofloxacin & $\begin{array}{c}\text { Cmax/MIC 6-8; } \\
\text { AUC }_{0-24} / \mathrm{MIC} \geq 87 \\
\mathrm{mg} \cdot \mathrm{h} / \mathrm{L} \text { (gram-negative); }\end{array}$ & $500 \mathrm{mg} \mathrm{q} 48 \mathrm{~h}$ & $\begin{array}{l}500-750 \mathrm{mg} \text { LD, } \\
250 \mathrm{mg} \mathrm{q} 24 \mathrm{~h}\end{array}$ & $\begin{array}{l}500-750 \mathrm{mg} \text { LD, } \\
250-500 \mathrm{mg} \text { q24h }\end{array}$ \\
\hline Ciprofloxacin & $\begin{array}{c}\mathrm{AUC}_{24} / \mathrm{MIC} \geq 50 \mathrm{mg} \cdot \mathrm{h} / \mathrm{L} \\
\text { (gram-positive) }\end{array}$ & $400 \mathrm{mg}$ q24h & 200-400 mg q12-24h & $400 \mathrm{mg} \mathrm{q} 12 \mathrm{~h}$ \\
\hline \multicolumn{5}{|c|}{ Miscellaneous } \\
\hline Colistin (CD) & $\begin{array}{l}\text { Free AUC/MIC } \\
10 \mathrm{mg} \cdot \mathrm{h} / \mathrm{L}\end{array}$ & N/A & $2.5 \mathrm{mg} / \mathrm{kg} \mathrm{q} 48 \mathrm{~h}$ & $\begin{array}{c}5-10 \mathrm{mg} / \mathrm{kg} \mathrm{LD}, \\
2.5-5 \mathrm{mg} / \mathrm{kg} \text { q24h }\end{array}$ \\
\hline Aztreonam (TD) & $\begin{array}{c}\geq 50 \% f \mathrm{~T} \geq 8 \mathrm{mg} / \mathrm{L} \\
\quad(P . \text { aeruginosa })\end{array}$ & $1 \mathrm{~g} \mathrm{q} 12 \mathrm{~h}$ & 2 g LD, 1-2 g q12h & $2 \mathrm{~g} \mathrm{LD}, 1-2 \mathrm{~g}$ q8-12h \\
\hline Linezolid (CD/TD) & $\mathrm{AUC} / \mathrm{MIC}=80 \mathrm{mg} \cdot \mathrm{h} / \mathrm{L}$ & $600 \mathrm{mg}$ q12h & $600 \mathrm{mg}$ q12h & $600 \mathrm{mg}$ q12h \\
\hline $\begin{array}{l}\text { Vancomycin } \\
\text { (CD/TD) }\end{array}$ & $\begin{array}{c}\text { AUC/MIC }=400 \mathrm{mg} \cdot \mathrm{h} / \mathrm{L} \\
\text { (Staphylococcus aureus } \\
\text { and S. pneumoniae) }\end{array}$ & $1 \mathrm{~g} \mathrm{q} 24-96 \mathrm{~h}$ & $\begin{array}{l}20-25 \mathrm{mg} / \mathrm{kg} \mathrm{LD}, \\
500-750 \mathrm{mg} \text { q12h with } \\
\text { TDM adjustments }\end{array}$ & $\begin{array}{l}25 \mathrm{mg} / \mathrm{kg} \mathrm{LD}, 15 \mathrm{mg} / \mathrm{kg} \\
\mathrm{q} 24 \mathrm{~h} \text { re-dose when } \\
\text { through concentrations } \\
\quad<15 \mathrm{mg} / \mathrm{L}\end{array}$ \\
\hline $\begin{array}{l}\text { Daptomycin } \\
\text { (CD/TD) }\end{array}$ & $\begin{array}{l}\text { AUC/MIC of } 75-237 \\
\mathrm{mg} \cdot \mathrm{h} / \mathrm{L} \text { for } S \cdot \text { pneumoniae, } \\
388-537 \mathrm{mg} \cdot \mathrm{h} / \mathrm{L} \text { for } \mathrm{S} \text {. } \\
\text { aureus, } 0.94-1.67 \mathrm{mg} \cdot \mathrm{h} / \mathrm{L} \\
\text { for Enterococcus faecium }\end{array}$ & $8 \mathrm{mg} / \mathrm{kg} \mathrm{q} 48 \mathrm{~h}$ & $6-8 \mathrm{mg} / \mathrm{kg}$ q24h & $6-8 \mathrm{mg} / \mathrm{kg}$ q24h \\
\hline \multicolumn{5}{|c|}{$\begin{array}{l}\mathrm{CD}=\text { concentration-dependent; } f \mathrm{~T}=\text { free serum concentration; } \mathrm{GNR}=\text { Gram-negative rod; } \\
\mathrm{IV}=\text { intravenous; } \mathrm{LD}=\text { loading dose; } \mathrm{N} / \mathrm{A}=\text { not available; } \mathrm{PO}=\text { orally; } \mathrm{q}=\text { every; } \\
\mathrm{TD}=\text { time-dependent; } \mathrm{TDM}=\text { therapeutic drug monitoring; } \mathrm{PD}=\text { pharmacodynamics; } \\
\mathrm{MIC}=\text { minimum inhibitory concentration; } \mathrm{AUC}=\text { area under the curve. }\end{array}$} \\
\hline
\end{tabular}




\subsection{Drug Administration Strategies}

In general, there are three strategies to administer any given drugs: (1) standard infusion (administer drug for $30 \mathrm{~min}$ ), (2) extended infusion (administer drug for 3-4 h), and (3) continuous infusion (administer drug for $24 \mathrm{~h}$ ). For critically ill patients, some suggest having a higher free drug concentration (e.g., $4 \times \mathrm{MIC}$ ) to maximize bacterial killing and suppress bacterial resistance [33]. For example, the $\mathrm{T} \geq \mathrm{MIC}$ goal for $\beta$-lactam agents is $40-60 \%$ [33]. However, patients who achieved concentrations above the MIC for the entire dosing interval ( $\mathrm{T} \geq$ MIC of $100 \%$ ) with cefepime or ceftazidime had higher cure rates ( $82 \%$ vs. $33 \%$ ) and higher bacterial eradication rates $(97 \%$ vs. $44 \%)$ than patients with $\mathrm{T} \geq$ MIC of $34-86 \%$ [35]. Thus, higher $\mathrm{T} \geq$ MIC targets should be considered with serious infections in critically ill patients. Due to decreased renal clearance, underdosing of antibiotic therapy is prevalent mainly because of drug toxicity concerns $[4,7,8]$. In reality, there is a higher mortality rate in critically ill patients due to an infection compared to a mortality rate from a drug toxicity. Antibiotic dosing strategies should be designed to take advantage of the CRRT, depending on the drug's PD targets.

The flowchart (Figure 1) illustrates which drug administration strategy would be advantageous, depending on the antibiotics' PD targets. For example, continuous or extended infusion with the LD (standard infusion) strategies should be used with a time-dependent antibiotic to maximize $\mathrm{T} \geq$ MIC in critically ill patients. As mentioned earlier, extended antibiotic infusions can maintain target steady-state serum concentrations in critically ill patients receiving CRRT [36]. However, these drug administration strategies are not yet considered as a standard practice [37], most likely due to lack of efficacy evidence in patients receiving CRRT. Despite the lack of study, this intervention should be considered in patients with severe infections, because it is a simple intervention that has been documented to improve the $\mathrm{T} \geq$ MIC. Extended or continuous infusion may not be appropriate in concentration-dependent antibiotics like vancomycin. Vancomycin continuous infusions $(16-35 \mathrm{mg} / \mathrm{kg} /$ day) with a loading dose of $15 \mathrm{mg} / \mathrm{kg}$ successfully reached target serum concentrations (20-30 mg/L) with CRRT [38]. However, $26 \%$ of patients had drug accumulations with serum concentrations greater than $30 \mathrm{mg} / \mathrm{L}$ on Day 3, leading to increased drug toxicity risk. Concentration-dependent antibiotics might pair better with bolus infusions, because they require high-peak concentrations to avoid drug-resistance from suboptimal antibiotic exposure [39]. Since patients receiving CRRT tend to be volume-overloaded, higher doses in short periods need to be administered to attain appropriate initial peak concentrations. Taccone and colleagues showed that patients receiving CRRT with severe sepsis required at least $25 \mathrm{mg} / \mathrm{kg}$ of amikacin as a loading dose to achieve target peak concentrations [40]. However, authors suggested to extended the dosing interval to $>24$ hours once the target peak serum concentrations are reached, due to a high amikacin concentration with a wide inter-variability [40]. Therapeutic drug monitoring should be utilized, if applicable, even with $\beta$-lactams to prevent underdosing and overdosing in critically ill patients receiving CRRT [8,41]. 


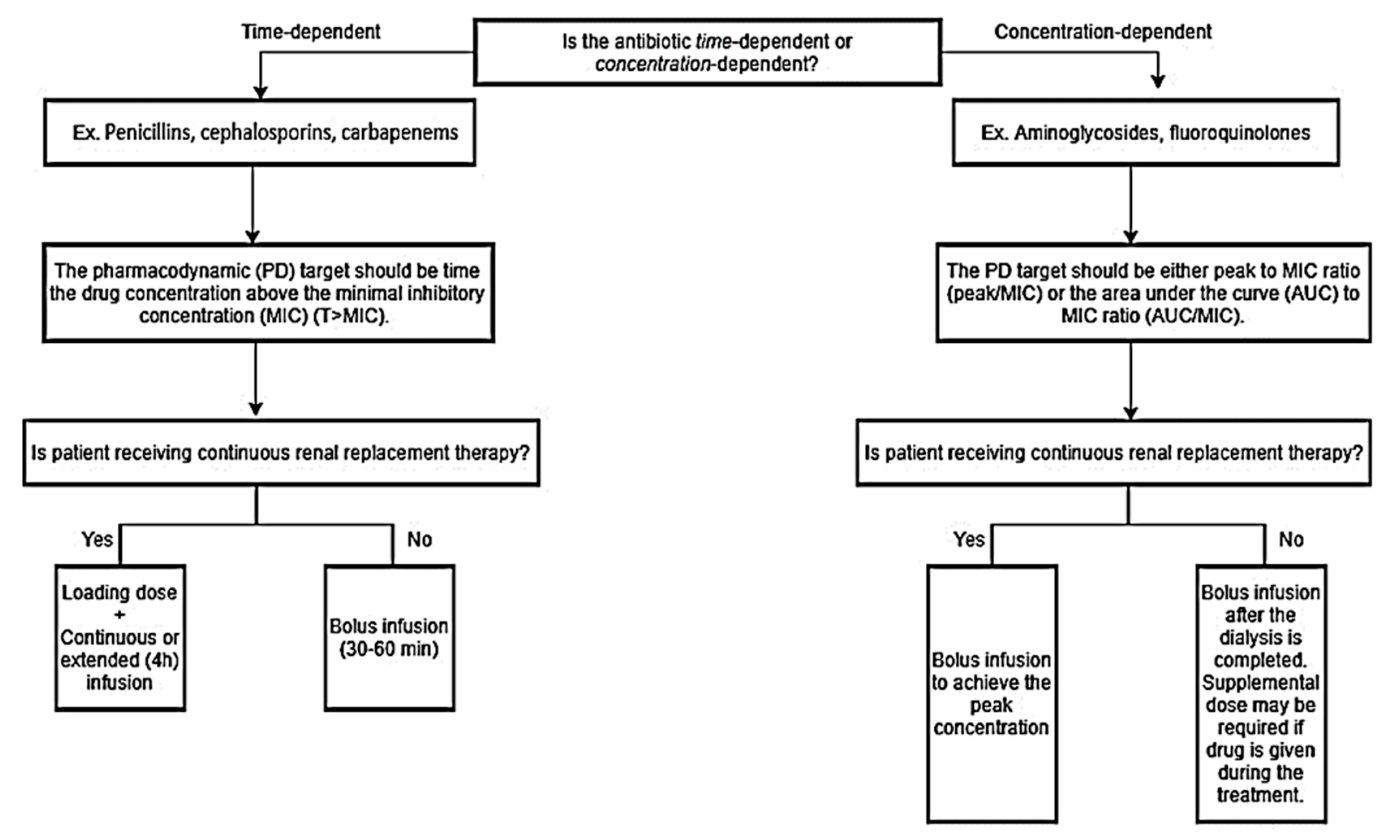

Figure 1. Drug administration strategy for time-dependent vs. concentration-dependent antibiotics for critically ill patients receiving renal replacement therapy.

\section{Conclusions}

Critically ill patients with AKI receiving CRRT require higher antibiotic doses than patients with kidney dysfunction, including end-stage renal disease (e.g., higher $\mathrm{CL}_{\mathrm{NR}}$, volume overload, and resistant organisms in the ICU). Drug dosing recommendations and drug administration strategies are intended to guide the clinicians to individualize therapy plans for their patients. It is indispensable to check local epidemiology and resistance patterns to select appropriate antibiotics to improve patient outcomes.

Author Contributions: Conceptualization, writing, visualization, S.M.J.; All authors have reviewed the final manuscript and approved it. All authors have read and agreed to the published version of the manuscript.

Funding: This research received no external funding.

Conflicts of Interest: The authors declare no conflicts of interest.

\section{References}

1. Barbar, S.D.; Binquet, C.; Monchi, M.; Bruyere, R.; Quenot, J.P. Impact on mortality of the timing of renal replacement therapy in patients with severe acute kidney injury in septic shock: The IDEAL-ICU study (initiation of dialysis early versus delayed in the intensive care unit): Study protocol for a randomized controlled trial. Trials 2014, 15, 270. [CrossRef] [PubMed]

2. Rhodes, A.; Evans, L.E.; Alhazzani, W.; Levy, M.M.; Antonelli, M.; Ferrer, R.; Kumar, A.; Sevransky, J.E.; Sprung, C.L.; Nunnally, M.E.; et al. Surviving Sepsis Campaign: International Guidelines for Management of Sepsis and Septic Shock: 2016. Intensive Care Med. 2017, 43, 304-377. [CrossRef] [PubMed]

3. Edrees, F.; Li, T.; Vijayan, A. Prolonged Intermittent Renal Replacement Therapy. Adv. Chronic Kidney Dis. 2016, 23, 195-202. [CrossRef] [PubMed]

4. Seyler, L.; Cotton, F.; Taccone, F.S.; De Backer, D.; Macours, P.; Vincent, J.L.; Jacobs, F. Recommended beta-lactam regimens are inadequate in septic patients treated with continuous renal replacement therapy. Crit. Care 2011, 15, R137. [CrossRef]

5. Tsai, D.; Stewart, P.; Goud, R.; Gourley, S.; Hewagama, S.; Krishnaswamy, S.; Wallis, S.C.; Lipman, J.; Roberts, J.A. Pharmacokinetics of Piperacillin in Critically Ill Australian Indigenous Patients with Severe Sepsis. Antimicrob. Agents Chemother. 2016, 60, 7402-7406. [CrossRef] 
6. Imani, S.; Buscher, H.; Day, R.; Gentili, S.; Jones, G.R.D.; Marriott, D.; Norris, R.; Sandaradura, I. An evaluation of risk factors to predict target concentration non-attainment in critically ill patients prior to empiric beta-lactam therapy. Eur. J. Clin. Microbiol. Infect. Dis. 2018, 37, 2171-2175. [CrossRef]

7. Lewis, S.J.; Mueller, B.A. Antibiotic Dosing in Patients With Acute Kidney Injury: “Enough But Not Too Much". J. Intensive Care Med. 2016, 31, 164-176. [CrossRef]

8. Lewis, S.J.; Mueller, B.A. Antibiotic dosing in critically ill patients receiving CRRT: Underdosing is overprevalent. Semin. Dial. 2014, 27, 441-445. [CrossRef]

9. Dellinger, R.P.; Levy, M.M.; Rhodes, A.; Annane, D.; Gerlach, H.; Opal, S.M.; Sevransky, J.E.; Sprung, C.L.; Douglas, I.S.; Jaeschke, R.; et al. Surviving Sepsis Campaign: International guidelines for management of severe sepsis and septic shock, 2012. Intensive Care Med. 2013, 39, 165-228. [CrossRef]

10. Castellanos-Ortega, A.; Suberviola, B.; Garcia-Astudillo, L.A.; Holanda, M.S.; Ortiz, F.; Llorca, J.; Delgado-Rodriguez, M. Impact of the Surviving Sepsis Campaign protocols on hospital length of stay and mortality in septic shock patients: Results of a three-year follow-up quasi-experimental study. Crit. Care Med. 2010, 38, 1036-1043. [CrossRef]

11. Ulldemolins, M.; Roberts, J.A.; Rello, J.; Paterson, D.L.; Lipman, J. The effects of hypoalbuminaemia on optimizing antibacterial dosing in critically ill patients. Clin. Pharmacokinet. 2011, 50, 99-110. [CrossRef] [PubMed]

12. Mueller, B.A.; Scarim, S.K.; Macias, W.L. Comparison of imipenem pharmacokinetics in patients with acute or chronic renal failure treated with continuous hemofiltration. Am. J. Kidney Dis. 1993, 21, 172-179. [CrossRef]

13. Tegeder, I.; Bremer, F.; Oelkers, R.; Schobel, H.; Schuttler, J.; Brune, K.; Geisslinger, G. Pharmacokinetics of imipenem-cilastatin in critically ill patients undergoing continuous venovenous hemofiltration. Antimicrob. Agents Chemother. 1997, 41, 2640-2645. [CrossRef] [PubMed]

14. Macias, W.L.; Mueller, B.A.; Scarim, S.K. Vancomycin pharmacokinetics in acute renal failure: Preservation of nonrenal clearance. Clin. Pharmacol. Ther. 1991, 50, 688-694. [CrossRef]

15. Matzke, G.R.; McGory, R.W.; Halstenson, C.E.; Keane, W.F. Pharmacokinetics of vancomycin in patients with various degrees of renal function. Antimicrob. Agents Chemother. 1984, 25, 433-437. [CrossRef]

16. Vilay, A.M.; Churchwell, M.D.; Mueller, B.A. Clinical review: Drug metabolism and nonrenal clearance in acute kidney injury. Crit. Care 2008, 12, 235. [CrossRef]

17. Nilsson-Ehle, I.; Hutchison, M.; Haworth, S.J.; Norrby, S.R. Pharmacokinetics of meropenem compared to imipenem-cilastatin in young, healthy males. Eur. J. Clin. Microbiol. Infect. Dis. 1991, 10, 85-88. [CrossRef]

18. Leroy, A.; Fillastre, J.P.; Etienne, I.; Borsa-Lebas, F.; Humbert, G. Pharmacokinetics of meropenem in subjects with renal insufficiency. Eur. J. Clin. Pharmacol. 1992, 42, 535-538. [CrossRef]

19. Christensson, B.A.; Nilsson-Ehle, I.; Hutchison, M.; Haworth, S.J.; Oqvist, B.; Norrby, S.R. Pharmacokinetics of meropenem in subjects with various degrees of renal impairment. Antimicrob. Agents Chemother. 1992, 36, 1532-1537. [CrossRef]

20. Giles, L.J.; Jennings, A.C.; Thomson, A.H.; Creed, G.; Beale, R.J.; McLuckie, A. Pharmacokinetics of meropenem in intensive care unit patients receiving continuous veno-venous hemofiltration or hemodiafiltration. Crit. Care Med. 2000, 28, 632-637. [CrossRef]

21. Ververs, T.F.; van Dijk, A.; Vinks, S.A.; Blankestijn, P.J.; Savelkoul, J.F.; Meulenbelt, J.; Boereboom, F.T. Pharmacokinetics and dosing regimen of meropenem in critically ill patients receiving continuous venovenous hemofiltration. Crit. Care Med. 2000, 28, 3412-3416. [CrossRef] [PubMed]

22. Wang, A.Y.; Bellomo, R. Renal replacement therapy in the ICU: Intermittent hemodialysis, sustained low-efficiency dialysis or continuous renal replacement therapy? Curr. Opin. Crit. Care 2018, 24, 437-442. [CrossRef] [PubMed]

23. Jang, S.M.; Mueller, B.A. Drug Dosing Considerations in Patients with Acute Kidney Injury and Continuous Renal Replacement Therapy; American College of Clinical Pharmacy: Lenexa, KS, USA, 2017; pp. 49-77.

24. Clark, W.R.; Mueller, B.A.; Alaka, K.J.; Macias, W.L. A comparison of metabolic control by continuous and intermittent therapies in acute renal failure. J. Am. Soc. Nephrol. 1994, 4, 1413-1420.

25. Mei, J.P.; Ali-Moghaddam, A.; Mueller, B.A. Survey of pharmacists' antibiotic dosing recommendations for sustained low-efficiency dialysis. Int. J. Clin. Pharm. 2016, 38, 127-134. [CrossRef]

26. Claure-Del Granado, R.; Macedo, E.; Chertow, G.M.; Soroko, S.; Himmelfarb, J.; Ikizler, T.A.; Paganini, E.P.; Mehta, R.L. Effluent volume in continuous renal replacement therapy overestimates the delivered dose of dialysis. Clin. J. Am. Soc. Nephrol. 2011, 6, 467-475. [CrossRef] [PubMed] 
27. Choi, G.; Gomersall, C.D.; Tian, Q.; Joynt, G.M.; Li, A.M.; Lipman, J. Principles of antibacterial dosing in continuous renal replacement therapy. Blood Purif. 2010, 30, 195-212. [CrossRef]

28. Network, V.N.A.R.F.T.; Palevsky, P.M.; Zhang, J.H.; O'Connor, T.Z.; Chertow, G.M.; Crowley, S.T.; Choudhury, D.; Finkel, K.; Kellum, J.A.; Paganini, E.; et al. Intensity of renal support in critically ill patients with acute kidney injury. N. Engl. J. Med. 2008, 359, 7-20. [CrossRef]

29. Jang, S.M.; Pai, M.P.; Shaw, A.R.; Mueller, B.A. Antibiotic Exposure Profiles in Trials Comparing Intensity of Continuous Renal Replacement Therapy. Crit. Care Med. 2019, 47, e863-e871. [CrossRef]

30. Aronoff, G.R.; Bennett, W.M.; Berns, J.S.; Brier, M.E.; Kasbekar, N.; Mueller, B.A.; Pasko, D.A.; Smoyer, W.E. Drug Prescribing in Renal Failure: Dosing Guidelines for Adults and Children, 5th ed.; American College of Physicians: Philadelphia, PA, USA, 2007.

31. Heintz, B.H.; Matzke, G.R.; Dager, W.E. Antimicrobial dosing concepts and recommendations for critically ill adult patients receiving continuous renal replacement therapy or intermittent hemodialysis. Pharmacotherapy 2009, 29, 562-577. [CrossRef]

32. Hoff, B.M.; Maker, J.H.; Dager, W.E.; Heintz, B.H. Antibiotic Dosing for Critically Ill Adult Patients Receiving Intermittent Hemodialysis, Prolonged Intermittent Renal Replacement Therapy, and Continuous Renal Replacement Therapy: An Update. Ann. Pharmacother. 2020, 54, 43-55. [CrossRef]

33. Drusano, G.L. Antimicrobial pharmacodynamics: Critical interactions of 'bug and drug'. Nat. Rev. Microbiol. 2004, 2, 289-300. [CrossRef] [PubMed]

34. Clinical and Laboratory Standards Institute (CLSI). Performance Standards for Antimicrobial Susceptibility Testing; Twenty-Fourth Informational Supplement; CLSI Document M100-S24; CLSI: Wayne, PA, USA, 2014.

35. McKinnon, P.S.; Paladino, J.A.; Schentag, J.J. Evaluation of area under the inhibitory curve (AUIC) and time above the minimum inhibitory concentration ( $\mathrm{T}>\mathrm{MIC}$ ) as predictors of outcome for cefepime and ceftazidime in serious bacterial infections. Int. J. Antimicrob. Agents 2008, 31, 345-351. [CrossRef] [PubMed]

36. Mariat, C.; Venet, C.; Jehl, F.; Mwewa, S.; Lazarevic, V.; Diconne, E.; Fonsale, N.; Carricajo, A.; Guyomarc'h, S.; Vermesch, R.; et al. Continuous infusion of ceftazidime in critically ill patients undergoing continuous venovenous haemodiafiltration: Pharmacokinetic evaluation and dose recommendation. Crit. Care 2006, 10, R26. [CrossRef] [PubMed]

37. Chant, C.; Leung, A.; Friedrich, J.O. Optimal dosing of antibiotics in critically ill patients by using continuous/extended infusions: A systematic review and meta-analysis. Crit. Care 2013, 17, R279. [CrossRef] [PubMed]

38. Covajes, C.; Scolletta, S.; Penaccini, L.; Ocampos-Martinez, E.; Abdelhadii, A.; Beumier, M.; Jacobs, F.; de Backer, D.; Vincent, J.L.; Taccone, F.S. Continuous infusion of vancomycin in septic patients receiving continuous renal replacement therapy. Int. J. Antimicrob. Agents 2013, 41, 261-266. [CrossRef]

39. Martinez, M.N.; Papich, M.G.; Drusano, G.L. Dosing regimen matters: The importance of early intervention and rapid attainment of the pharmacokinetic/pharmacodynamic target. Antimicrob. Agents Chemother. 2012, 56, 2795-2805. [CrossRef]

40. Taccone, F.S.; de Backer, D.; Laterre, P.F.; Spapen, H.; Dugernier, T.; Delattre, I.; Wallemacq, P.; Vincent, J.L.; Jacobs, F. Pharmacokinetics of a loading dose of amikacin in septic patients undergoing continuous renal replacement therapy. Int. J. Antimicrob. Agents 2011, 37, 531-535. [CrossRef]

41. Economou, C.J.P.; Wong, G.; McWhinney, B.; Ungerer, J.P.J.; Lipman, J.; Roberts, J.A. Impact of beta-lactam antibiotic therapeutic drug monitoring on dose adjustments in critically ill patients undergoing continuous renal replacement therapy. Int. J. Antimicrob. Agents 2017, 49, 589-594. [CrossRef]

(C) 2020 by the authors. Licensee MDPI, Basel, Switzerland. This article is an open access article distributed under the terms and conditions of the Creative Commons Attribution (CC BY) license (http://creativecommons.org/licenses/by/4.0/). 